\title{
Architectural Transformation of Taiwan's Buddhist Middle Schools Founded in the Japanese Colonial Period
}

\author{
Huey-jiun Wang $*^{1}$ and Tien-hao Huang ${ }^{2}$ \\ ${ }^{1}$ Associate Professor, Department of Architecture, National Taiwan University of Science \& Technology, Taiwan \\ ${ }^{2}$ Ph.D. Student, Department of Architecture, National Taiwan University of Science \& Technology, Taiwan
}

\begin{abstract}
In the Japanese Colonial period (1895-1945), Japanese Buddhists built branch monasteries in Taiwan to proselytize; they also set up schools, which, after World War II, were transformed into non-religious, private schools, which continue to coexist with public schools. This paper takes the Private Taiwan Buddhist Middle School as an example to illustrate its background and academic activities in connection with the space and form of its campus buildings. It also examines the development and changes in Buddhist-run school architecture at various stages. All these things make it clear that in spite of the unwillingness of the authorities to consent to privately-sponsored middle schooling at first, the ardent desire the Taiwanese people expressed for education later turned the fate of their schools around. The schools eventually earned official support, and became certified, changing from academies for trainee priests into public-school equivalents for ordinary people. Accordingly, the architecture of the school buildings took a favorable turn away from the traditional Buddhist temples toward modern western-style complexes.
\end{abstract}

Keywords: Japanese colonial; Buddhism; middle school; private school; Soto Zen

\section{Introduction}

\subsection{Background and Purpose}

During the Chinese Qing Dynasty, public schools and private academies coexisted with the aim of allowing students to pass exams for official posts. On the other hand, the Presbyterian Churches founded schools in Taipei and Tainan in 1880 s, which became the oldest private middle schools. When the Japanese began to govern Taiwan in 1895, they first built national language institutes in order to solve communication problems, which later became elementary public schools. Middle schools were founded later, especially those for Taiwanese. Finally there were over 35 public middle schools (including girls' and boys', Japanese and Taiwanese) and eight private middle schools had been founded by the end of the Japanese Colonial period. Most of the middle schools still exist today. However, there are some private middle schools which are less-known in that they were founded by Japanese Buddhist sects during the Japanese Colonial period in Taiwan.

At the time there were eight Buddhist sects in Japan

*Contact Author: Tien-hao Huang Ph.D. Student, Department of Architecture, National Taiwan University of Science \& Technology. No. 56, Sec. 3, Shinglung Rd., Wenshan Chiu, Taipei, Taiwan 116, R.O.C.

Tel: +886-2-29313416 Ext. 2197 Fax: +886-2-2930-1874

e-mail: thhuang@cute.edu.tw

(Received June 27, 2006 : accepted January 12, 2007) with 14 sub-groups coming to Taiwan to evangelize; the most energetic sects were: Soto Zen, Rinzai Zen, the Joto sect, Honganji-ha and Otani-ha of the Jodoshin sect (Matsukane, 1998). Those sects not only built branch monasteries in Taiwan to proselytize; they also set up various schools.

Buddhist-run schools survived two world wars as well as government transfers and they still exist. A representative one is the Taiwan Buddhist Middle School (台灣佛教中學林), set up by Soto Zen. It is now known as Tai-bei High School (泰北中學).

Relevant studies on school architecture have dealt predominantly with government-run public schools, like Yamamoto (1999) or Sue (2001); and several articles have been devoted to the study of the foundation of Buddhist schools such as Fujii (2000), Shi, H.Y. (2003) or Matsukane (2004). However the architecture of Buddhist schools has never been examined. Therefore the purpose of this paper is to investigate the relationship between the foundation and architectural form of the Buddhist schools, in order to explore the characteristics and transformative process of Buddhist-run schools, as well as the implications of the transformations.

\subsection{Methodology}

This paper takes the Taiwan Buddhist Middle School as an example to illustrate its background and academic activities in connection with the form of the campus buildings. Further, we are using the original old pictures and graphs to confirm the architectural site plan and form in an attempt to restore the original look 
of the campus buildings at various stages.

The methodology is based on a review of official files, memoranda, documents from the Taiwan Governor-General's Office under Japanese rule, history books, handbooks and journals of the school, and written records of the Japanese Buddhist sects to understand the initiation, transformations and academic activities of the schools, to analyze their developmental events and, to examine their historical features from the social backgrounds, related laws and regulations. Through their historical backgrounds and the distinctive nature of the architectural realities, we can understand how the buildings were transformed.

\section{Establishment and Transition}

\subsection{How Soto Zen was transmitted to Taiwan}

In 1895, Soto Zen Buddhist Priest Sasaki (佐佐木珍龍) came to Taiwan with the 2nd Army Corps and started spreading the faith at the Long-shan Temple in Taipei. Most of his congregation were Taiwanese, to whom he also taught the Japanese language. In 1907, Sasaki proposed opening branch monasteries in Taipei, Hsinchu, Taichung and Tainan. The foundation of the Taipei Branch was laid just outside the east gate, thanks to a land donation from a devotee named Arakawa, to the funding support from the Soto Zen head temple in Japan, and to financial donations from other devotees. With approval from the Taiwan Governor-General's Office, the main hall (本堂) and living quarters (庫 裡) were completed in 1910. Unfortunately the entire building was destroyed by a typhoon in 1912, and not until 1920 were sufficient donations collected for its reconstruction. The new RC Main Hall was completed in 1923 and the Bell Tower, which still remains, was erected in $1930{ }^{1}$

Due to the difference in worship rituals and practice between local and Japanese Buddhists, and in order to attract Taiwanese followers, the branch temple assigned a Taiwanese Master Priest to raise funds to build the Kuan-yin Zen-hall (觀音禪堂) for local Buddhists (Shi, Y. L., 2004). With approved funds totaling $¥ 10,724$, $¥ 4,000$ from the Soto Zen headquarters and $¥ 500$ from the Taipei Branch plus other local donations, the Kuan-yin Zen-hall was completed in 1915, earlier than the reconstruction of the main hall. ${ }^{2}$ Seen from the extant drawings, it is typical of a traditional Taiwanese wooden temple with a swallow-tail roof and a pair of dragon pillars in front of its entrance. Noteworthy is that a Japanese designer named Den Minoru drew it based on a precise scale. (Fig.1.)

\subsection{The Founding of the Taiwan Buddhist Middle School (1916-1922)}

The Taipei Branch Head of Soto Zen, Oishi Kento (大 石堅童), seeing the effective proselytizing done by the Taiwan Youth Buddhism Association in the competitive exhibition for encouragement of industry (勸業共進會), collaborated with local gentry and monks on setting up a Buddhist middle school. They announced their

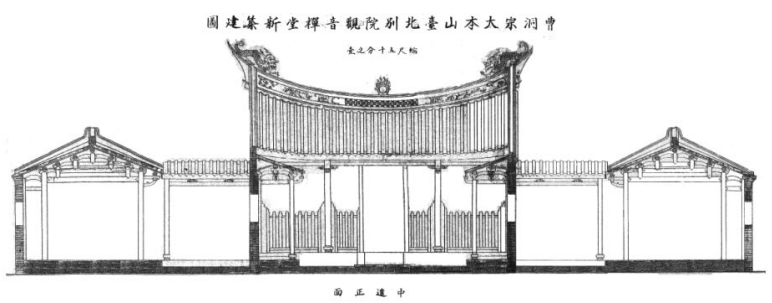

Fig.1. Original Design Drawing of the Kuan-yin Zen-hall

plan among all the temples island-wide, seeking their donations, and making a proposition to the head temple in Japan at the same time. Meanwhile the headquarters of the Soto Zen ran one university and four middle schools in Japan.

At that time abbots of the Long Hwa group of the Taiwanese Taoist-Buddhist Zai sect (齋教龍華派) united with the Soto Zen temples; thus allowing their disciples and devotees to attend Japanese Buddhist schools for diplomas which might offer them a logical channel to succeed to the abbotship. Those devotees, after being trained at the Buddhist school, incorporated their temples into Soto Zen (Shi, H.Y., 2003).

In 1916, Rinzai Zen started the Chin-nan academy (鎮 南學寮) in Taipei, intended to educate Taiwanese monks and followers, and aiming to put all the Taiwanese temples under the charge of Japanese Rinzai Zen (Shi, H.Y., 2003). This meant that competition among the divers religious sects could be instrumental in creating a climate for the establishment of schools.

In the same year, the Taiwan Buddhist Middle School (台灣佛教中學林) appealed to the Japanese head temple to subsidize the opening of a school and filed their application to the Taiwan GovernorGeneral's Office stating that the purpose of the school is "to educate Taiwanese monks and followers and, to transmit doctrinal knowledge in order to cultivate the character of abbots." The school launched a three-year course program and a one-year extension program and started recruiting eligible graduates who completed four years of public school education or equivalents. The subjects included: the Soto doctrine, the religious tenets of other sects and common courses on general education (Japanese \& Chinese, and History $\&$ Geography). The weekly study schedule consisted of 31 hours, of which five hours were allotted for Buddhist studies. ${ }^{3}$

The application also writes, "The school is within the Taipei Branch of the Soto Zen temple, situated at the East Gate of Taipei with classrooms and dormitory temporarily placed in the Kuan-yin Zen-hall." The main hall was used as an auditorium, and the rear hall, divided into three chambers, gave one space for an office and two for temporary classrooms (Fig.2.). The living quarters of the monastery were utilized as temporary dormitories. The application also attached a proposed expansion plan for the school. On the right side of the main hall, chambers were built for a dormitory, while the left side was for classrooms 
and offices. The application was approved by the Governor-General's Office and the opening ceremony held in front of the Kuan-yin Zen-hall in 1917 (Fig.3.).

The plan shown below - surrounding the main hall was space for dormitories and lecturing - was similar to those originally made for Zen-practice. And the Kuan Yin Zen-hall was modeled on a typical Taiwanese traditional form. Seen in old photographs are the teachers and students, both wearing surplices in class (Fig.4.).

In 1917, there were 33 students admitted for the first academic year, while in the second year, the school amended its rules to recruit not only priests and followers, and not all students needed to lodge. The

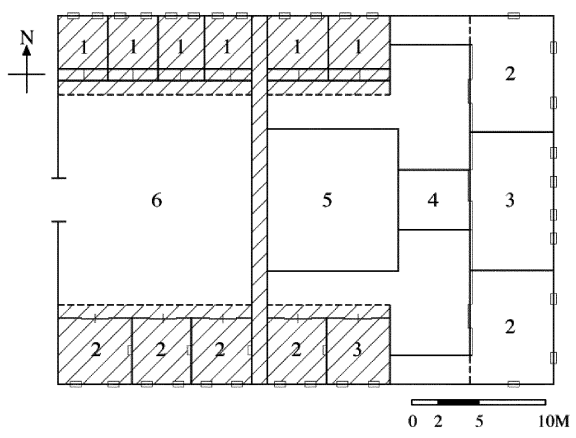

1. Dorm

2. Classroom

3. Administrative Office

4. Covered Corridor

5. Lecture Hall

6. Central Court

$\mathrm{T}$ The proposed expansion part Plan for

Fig.2. Plan of the Taiwan Buddhist Middle School in the application (1916)

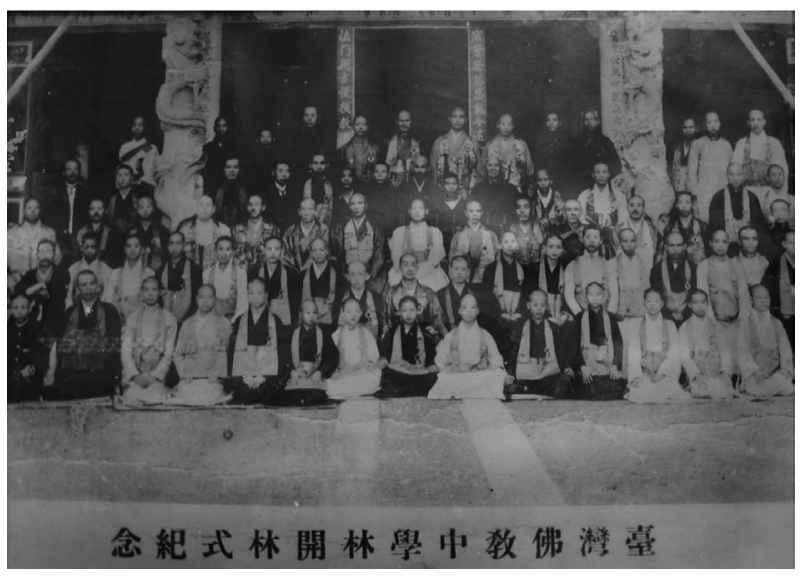

Fig.3. The Opening Ceremony at the Taiwan Buddhist Middle School (1917)

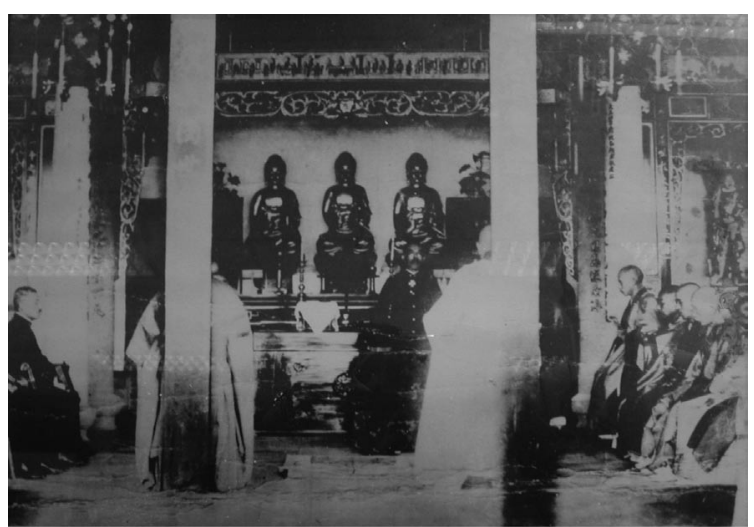

Fig.4. At Class in the Taiwan Buddhist Middle School (1917) next year, the first graduation ceremony was held with nine graduates and four were admitted to the Japanese Soto Zen's fourth Middle School to continue the fiveyear program. As a matter of fact, Soto Zen's Taipei Branch was first meant to be modeled on the five-year high school system that then prevailed in Japan, but the Governor-General opposed this because the Taiwan public school system had not yet run a five-year program. Thus, a three-year system was adopted and as a make-up measure, graduates desiring further study could be admitted without taking an entrance exam to the Soto Zen's middle school in Japan to carry on the fourth year (Shi, H.Y., 2003).

Concerning follow-up recruitments, an advertisement in the Taiwan Daily News (台灣日日新報), Feb. 8, 1921, reads, "It is a misunderstanding among the public who regard Taiwan Buddhist Middle School as a priest training school; it is actually wrong." Clearly, the adjustment was meant to boost its recruitment of wider-based students. That July, the students increased to 80 and that made the existing space and budget insufficient to support the school. In some related oral history and the Taiwan Daily News of July 1, 1935, the Principal of the middle school revealed having to seek funds outside to make both ends meet.

\subsection{Soto Zen Taiwan Middle School (1922-1935)}

In 1922, a new regulation was published in the Taiwan Education Order on private schools. The Taiwan Buddhist Middle School applied to change its name to "Soto Zen Taiwan Middle School". ${ }^{4}$ With the title "Buddhist" removed, the school became a general middle school based on the spirit of Buddhism. In its application, the "reason for name change" states, "The times are gone for making Buddhist teaching and proselytizing exclusive to priests and followers; now it's the time to educate the general public and instill in them Buddhist beliefs." Records also show, "To manage and maintain the school, the school received an annual subsidy of $¥ 2,600$ from the Department of Religious Affairs of Japanese Soto Zen." It required three years for graduation; the main courses were Civic Education, Buddhism, Japanese \& Chinese, and English; and study periods per week totaled 30 hours with only two hours for Buddhism. A cut in Buddhism study time was seen from five hours at the Buddhist Middle School to two and less at the new-name school, reflecting the changed purpose and nature of its teaching programs.

Based on the enclosed campus plan in the application, added chambers were already built on both sides of the Kuan-yin Zen-hall for use as a dormitory. On either side of the rear hall, the space originally kept for temporary classrooms was now used as a dining room and dormitory. The living quarters in the wing chambers on both sides were Japanese-style tatami rooms with built-in storage space (押入) and an entrance vestibule for removing shoes. The plan and architectural form was typically traditional Taiwanese, 
but the new features, like raised flooring, installed tatami mats and the below-floor vents seen on the walls, appeared to be adapted from Japan.

The classrooms, originally planned for the wing chambers, were located in a new two-story building to the front right of the Kuan-yin Zen-Hall. This building was completed in 1922. There were classrooms, an office, a library, a rest room and three classrooms upstairs. Although it is next to the temple, its architectural form appeared entirely western-style. (Fig.5.)

The above-mentioned Rinzai Zen Chin-nan academy, which was founded in the same year Soto Zen opened theirs, decided to close down owing to decreased student numbers making it hard to maintain. Their students were transferred to the Soto Zen Middle School, which then became the unique Buddhist-run

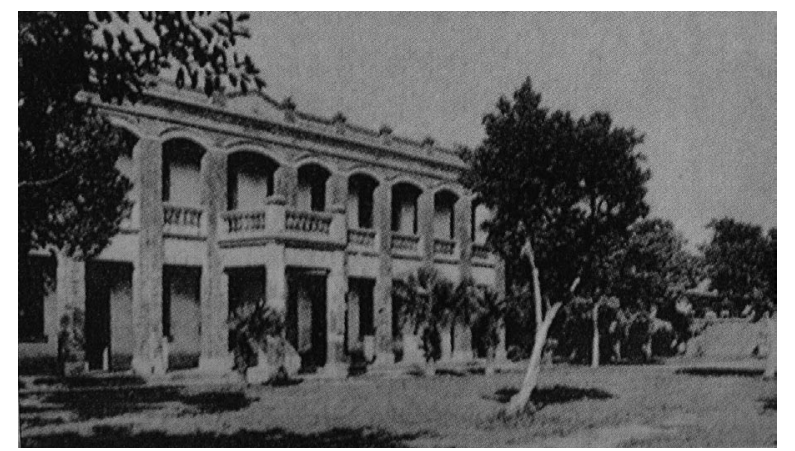

Fig.5. New Building for Classroom, Office and Library (1922)

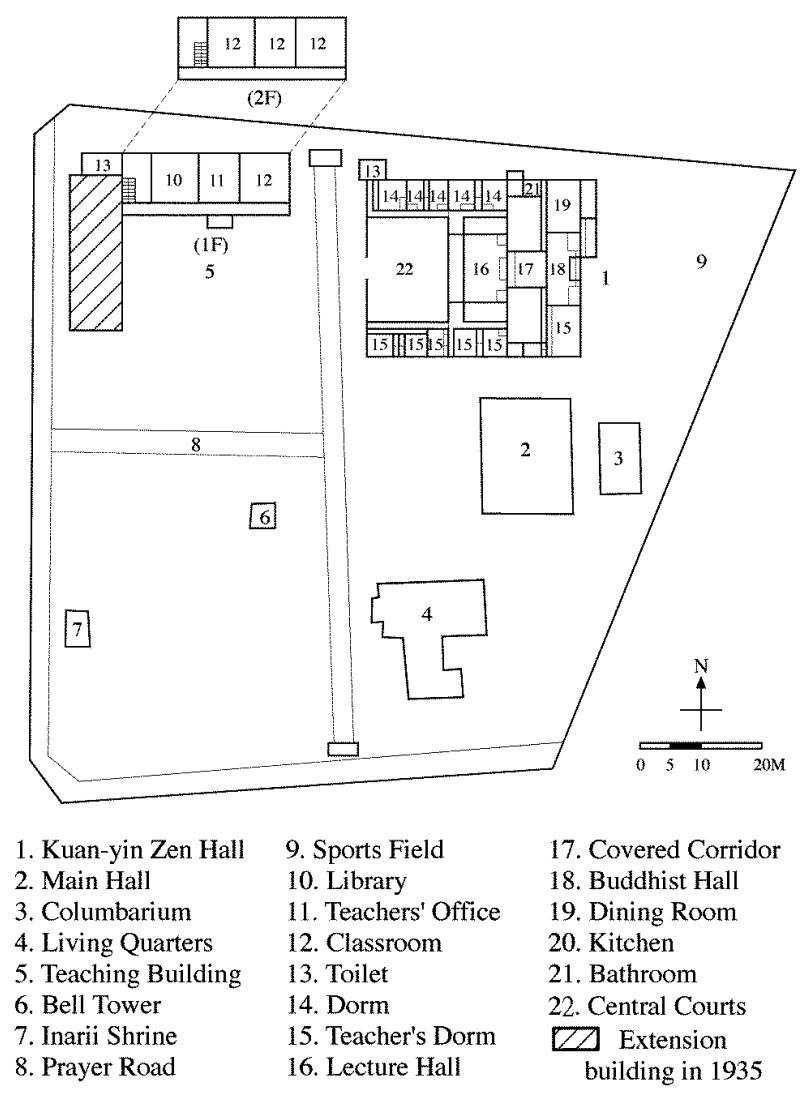

Fig.6. Site Plan in the Application for the Soto Zen Taiwan Middle School (1922 1935) middle school (Shi, H.Y., 2003).

The Soto Zen Middle School received a part of the temple space for the campus, changed the wings originally planned for classrooms into dormitory space for staff, teachers and students, and, for classroom use, began constructing new western-style buildings elsewhere. Also, the Buddhism course was cut in order to encourage ordinary people to attend. Such a change enabled the school to satisfy the order from the government, then to recruit a stable number of students, and survive.

\subsection{Private Taipei Middle School (1935-1945)}

In 1933, the Department of Religious Affairs of Japanese Soto Zen announced a guideline demanding all the schools become financially independent or be abolished. The new head of the sect's Taiwan branch, Shimada (島田弘舟), and teacher Togasi (富堅清玄) intended that private schools, though not socially powerful, could not be abolished, because they were among the few educational institutions that represented and served the Taiwanese population. Shimada and Togasi therefore actively advocated raising the status of the middle school to be on a par with a public five-year middle school to avoid being closed down (Matsukane, 2004). The Religious Bulletin reports that the Soto Zen Taiwan Middle School was granted approval to change its name to "Private Taipei Middle School", and became a five-year program similar to a general public middle school. At the same time, the Taipei Middle School was subsidized to construct a building, beginning on September 20 and completed in December, annexed to the old building to form a twostory "L-shape" campus complex as planned in 1935 (Fig.6.). ${ }^{5}$

In 1936, according to the Taiwan Daily News of April 7, 1936, the Soto Zen School, which was seeking official recognition, had 230 students and was striving for more. The school formed a legal corporation foundation, in a move to be accepted as a regular public school. Togasi was said to consult the Governor-General's Office councilors and Taipei Prefecture Education Department who said that an officially admitted middle school was required to own adequate physical facilities to house 1,000 students or more, a gym for martial arts, a science laboratory, a library and a sports field. The school, therefore, had no choice but to move out of the monastery to a larger premise elsewhere in order to attain the needed space (Matsukane, 2004).

The next year (1937), the school leased land in Shi-lin to build temporary wooden houses. These buildings, which were erected around the center of the campus enclosing an open space for assembly and sports, housed a gym and auditorium (Figs.7., 8.). All the buildings were completed the next year for students to move into, while the old campus remained as a women's division.

According to the 1939 issue of the handbook, 


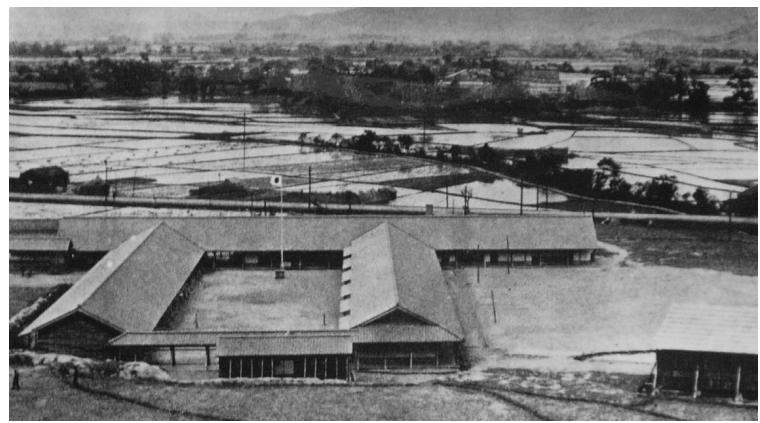

Fig.7. A Bird's-eye View of the Whole Campus (1938)

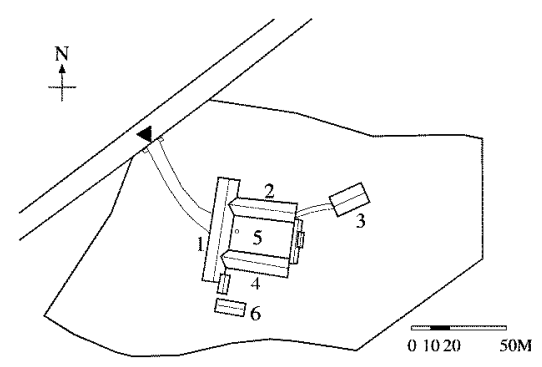

1. Administration Building

2. Teaching Building

3. Gymnasium

4. Dome

5. Sports Field

6. Dining Room \&

Kitchen

Fig.8. Site Plan of the Taipei Middle School (1938)

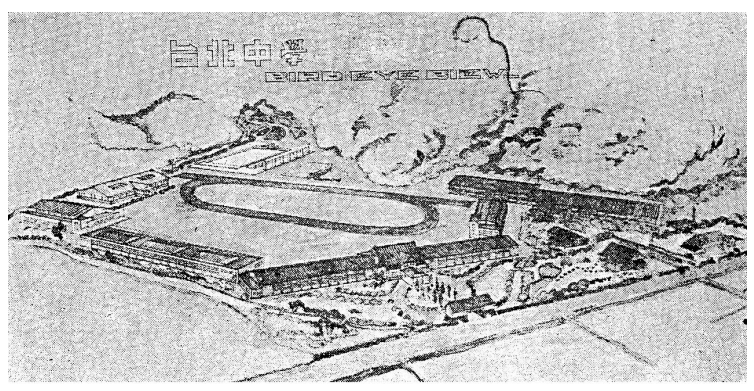

Fig.9. Expansion Plan of the Taipei Middle School (1939)

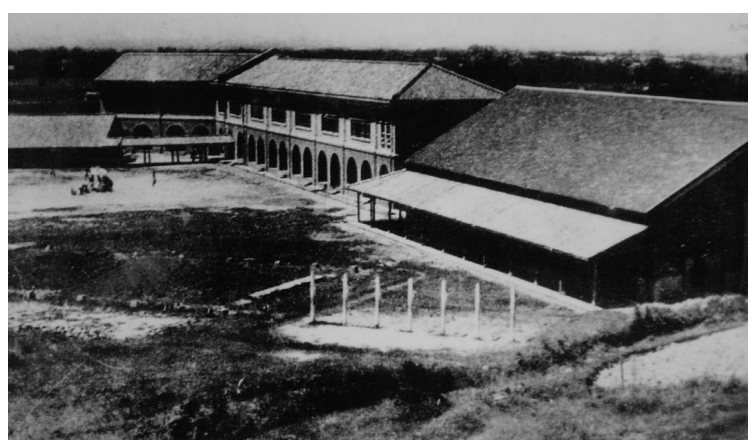

Fig.10. Newly-built buildings and Martial Arts Gym (1942)

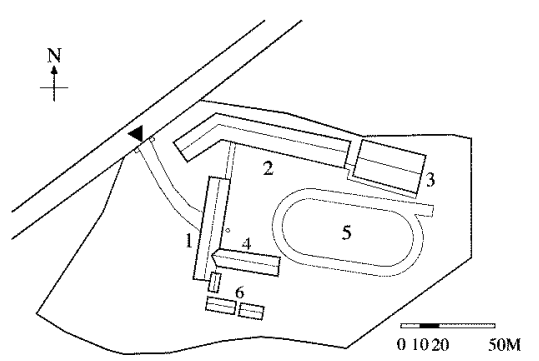

1. Administration Building

2. Teaching Building

3. Gymnasium

4. Dome

5. Sports Field

6. Dining Room \& Kitchen

Fig.11. Site Plan of the Taipei Middle School (1942)
A Brief Introduction to the Private Taipei Middle School, though they were for temporary use, the school contained classrooms for general and special purposes, a gym for indoor sports, a sports field, an administration office and a dormitory. The total campus area was $34,552 \mathrm{~m}^{2}$. The school then basically contained all the needed space required for a recognized public middle school.

In 1938, the Bureau of Cultural \& Educational Affairs of the Governor-General's Office published "The Standard Code for Recognized Private Middle Schools with the Status of Public Middle Schools." Under sustained efforts as mentioned above, the Private Taipei Middle School, with a new campus and a legal corporate foundation in place, was recognized. Thereafter, the graduates had the same status as those from a public school. ${ }^{6}$ In 1939, the School received a subsidy grant of $¥ 4,000$ from the government. ${ }^{7}$

The subjects included: Virtue-cultivation, Civic Education, Japanese \& Chinese, History \& Geography, English, Math, Science, Arts, Music, Vocational and Physical Education. The courses were the same as those given at the public middle school and no Buddhism courses were included.

In the early stage of moving out of the temple, constraints of time and budget made it necessary for the school to first erect wooden buildings for temporary use prior to starting the phased expansions. The plan for the middle school expansion was featured on the cover of the handbook (Fig.9.). It depicts the building complex to be placed along the margin of the site where the administration building stands and connects, on either side, the space allotted for use in teaching, living and indoor activities. The sports field is enclosed by the building complex. The front of the campus, bordering the outbound road reserved a space for landscaped gardens and living quarters for the staff. In the chapter on "School Expansion Plan" of the handbook, it records, "the RC buildings are constructed based on the phased plan." And so, all the wooden buildings erected in 1938 were partially pulled down in 1942 and a new two-story teaching building and gym were constructed. The old buildings on the north were first demolished. There was a corridor to link the new buildings complex on the same side - all the way to the other end where the gym stands (Figs. 10,11). The temporary buildings in the center were there to reserve

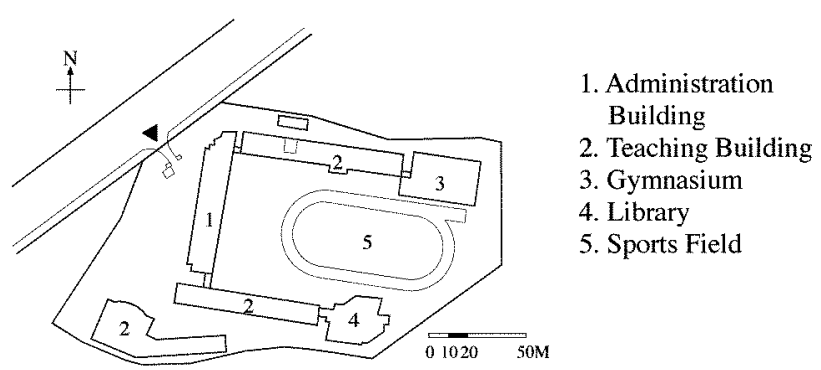

Fig.12. Site Plan of the Tai-bei High School (1999) 
a region for the permanent buildings to be constructed based on the expansion plan.

\subsection{The Post-war Tai-bei Middle School (泰北中學)}

After the war, Private Taipei Middle School changed to a non-religious, private school and its name became Tai-bei (泰北) High School. The aerial photograph taken in 1961 shows the wooden buildings being gradually demolished and replaced by the low-level RC buildings (later also pulled down for rebuilding). In 1978, on the north and south sides, four-or five-story $\mathrm{RC}$ buildings were constructed. In 1983, the west wing was completed, as was the new gym on the site of the old one. It indicates that the site plan of the Tai-bei High School today follows the architectural site plan blueprint drawn in 1939 (Fig.12.).

\section{Issues for Buddhist-run Middle Schools}

After investigating the transition of a Buddhist-run middle school, we shall look more carefully into the factors which affected architectural transformations, including the government policies, social background and architectural form at the time.

\subsection{Governmental Regulations}

According to the record of Annals of Education History (1939), Priest Matsu-ura of the Zin-gu Sect (神宮教) proposed to set up the Manka School and Hongaji-ha Buddhists applied to set up the Ryukoku Academy in 1896 . The permit cases were handled by a local government. But, an inspection found that only Manka Academy was running while others ceased to operate after several months. Therefore, the Education Department announced the "Regulations on the Establishment and Abolishment of Private Schools" in 1898 , in order to close down those poorly managed schools. The next year, the Department further amended the above regulations to require that all the Presbyterian Church-run schools founded prior to the Japanese rule must file applications for permits in order to be officially recognized.

Later, in 1905, promulgation of the Private School Law (Taiwan Governor-General's Office Order No. 58) required that the application must enclose a site plan for campus and student dorm buildings, along with qualifications and vitae curricula (VC) of the founder and teachers for review. In 1919, the Taiwan Education Order was issued to regulate extant private schools which would be allowed to continue to operate, but, among the new applicants, only vocational schools and special skill schools would be permitted to open.

In 1922, Articles 2 and 4 of the Private School Law, made the regulations for public schools applicable to similar-type private schools. Also, in order to open middle schools, women's high schools or vocational schools, the applicants were required to reserve adequate funds and form a legal-corporate foundation. Article 19 on teacher qualifications further ruled that all the unqualified teachers must submit their Vitae Curricula and subjects taught to obtain certificates from the prefectural government.

The Taiwan Daily News, Jan. 20, 1938, reported that, as the number of graduates from primary schools was greatly increasing, more and more of them desired to continue studying. The pubic greatly expected that more public and private schools would be set up and existing private schools would be recognized. To address the issue, the Education Department consented to recognize private schools with the equivalent status as public schools as long as they conformed to the set standard. In the past, all the private schools were regarded as "similar-type" schools and their diplomas were not officially certified. The standards for a solid and sound private school to be recognized included: (1) a reserve of $¥ 100,000$ as operating funds ( $¥ 80,000$ for women's schools); (2) a foundation with its chairman and board members elected by a proper process without meddling by school personnel and (3) an equivalent-to- public-school pay scale for qualified teachers. In fact, the regulations were the same as the articles of the Educational Order of 1922, also restating the requirements for hardware, that is, management and maintenance of facilities, and software, that is, educational content, along with selection of board members, and qualifications of teachers and staff members. After an inclusive assessment, if it improved and met the standards on a par with public schools, the private school would be given an opportunity to be recognized.

The above-mentioned changes in regulations show the Japanese ruling authorities changed from a repressive attitude toward these private schools, to an encouraging one. Basically, they initially took a passive attitude to cope with the de facto private schools, using controls and restrictions, particularly, on middle schools, women's middle schools and special skill or vocational schools until 1938, when the authorities accepted the realities and recognized their diplomas.

\subsection{The Social Backgrounds}

When the Japanese Government began its rule in Taiwan, in respect of basic education, they first built national language institutes and later popularized public elementary schools. These contributed largely to the rapid-growth of the attendance rate of Taiwanese students; however, they were not so enthusiastic in providing further study for the graduates. At that time, there were two kinds of schools after the elementary schools; one was middle school; another was trade- or skill-training vocational schools and teachers' colleges, but most of them were for Japanese students.

Early in Japanese rule, most Taiwanese students had to go to Japan to pursue higher education. At that time, the Taiwanese elite, affected by deep-rooted ideas about Chinese imperial civil examinations, had long thought highly of their children's education. With sustained efforts, the gentry called on the Governor-General's Office, who also needed their support, to approve of the Taiwanese-founded Public Taichung Middle School 
in 1915 (Fujii, 2000). In 1922, the guideline allowing both Taiwanese and Japanese students to study on the same campus was issued under the Taiwan Education Order; from then on more middle schools were opened in all other prefectures. According to statistics from Taiwan's Governor-General's Office, from 1922 to 1930, the number of Taiwanese students in public middle schools island-wide had increased from about 1,300 to 3,300 (whereas the Japanese students in Taiwan increased from 2,900 to 6,600 ). However, the number of Taiwanese graduates from the elementary schools had increased from 195,783 in 1922 to 248,693 in 1930, (whereas the Japanese graduates had increased from 21,801 to 34,124$)$. This contrast shows that there still was an evident shortage of schools for those Taiwanese students wishing to continue studying.

The Jodoshin sect, Hoganji-ha, had early predicted this trend, and was willing to set up a general middle school for the Taiwanese students early in $1915^{8}$ However that application was rejected because the Governor-General's Office insisted on governmentcontrolled schooling and discouraged private sponsors. It was then hard to open private middle schools. The Japanese even extended control and restriction onto all the schools founded by churches and missionaries. Around 1930, there were only five private Churchrun schools and the Private Soto Zen Middle School, the Private Tainan Vocational Academy (founded by the Japanese Jodo sect in 1918) and Private Taiwan Commerce \& Industry School (founded by the Toyo Society in 1917) plus evening schools. ${ }^{9}$ From 1922-1930, the total number of students in all the private schools increased from around 1,300 to 1,900 (whereas the number of Japanese students remained 1,000 or so).

Therefore, apparently prior to the 1930 s, there were only $2 \%$ of Taiwanese elementary graduates who could pursue higher academic career. As previously cited from the Taiwan Daily News's report, since public schools could not satisfy the needs of the increased numbers of students for further study, private schools became another channel for the Taiwanese. Hence, expanding public schools and recognizing private schools were the solutions to the school shortage.

In 1939, the Private Taipei Middle School was officially recognized; at that time other formally recognized private middle schools and public middle schools numbered 22 (11 each for men and women). According to 1941 statistics, the Taiwanese students in middle schools increased to 9,432 and the Japanese to 18,126 . The number of students in the Private Taipei Middle School increased annually by around 100 (Fig.13.). The trends and situations of the times also offered opportunities for enlarging the school.

\subsection{The Architectural Form of Middle Schools}

Considering campus architecture, school buildings under the Japanese rule in Taiwan were influenced by westernization. Take the First Taipei Prefectural Middle School, founded in 1908, for example (Fig.14.). It has a wide winding corridor which borders to blend with a central court; the corridor on the first floor is squarearched while the second floor is semi-circle arched. It also has a sloping roof and a raised floor. Basically, it had very much a western-style architectural form. In contrast, the Soto Zen Middle School first used the Kuan-yin Zen-hall, a Taiwanese style temple as their campus, but later, due to the change of recruiting strategy, built their new building adopting the architectural form public schools used even on the same site.

In Togasi's memoir, he revealed how he chose between staying and moving out of the temple. To move meant to break away from the monastery and risk losing support from the head temple in Japan; to stay within the temple would lose the chance to be recognized by the government as a middle school. Given the practical problems faced by all the private schools, most were forced to close down. It was because of the strong will of the then school principal and Togasi, who maintained the necessity of sustaining a private middle school, that giving up the school-within-a temple concept and moving out

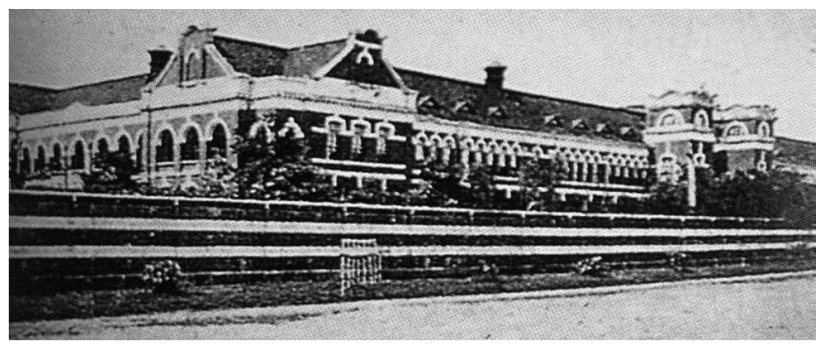

Fig.14. The First Taipei Prefectural Middle School

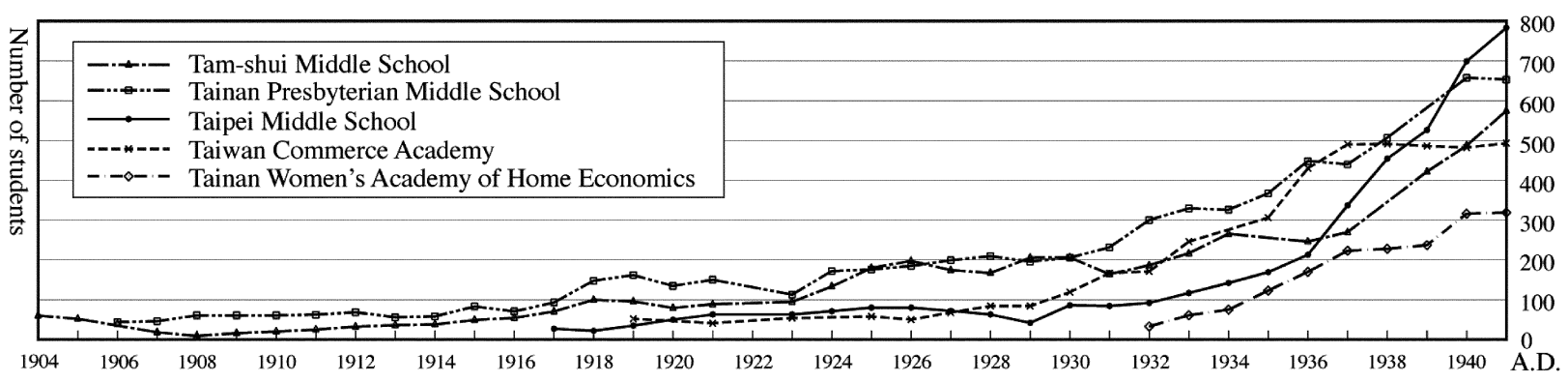

Fig.13. Number of Students of Private Middle Schools in Japanese Colonial 
of the temple was possible. The school buildings at the new location were constructed in light of actual development and expansion; they were thus entirely devoid of any Buddhist atmosphere. They were brave enough to make changes in both the academic content and architectural hardware, to cope with the actual situation, thus enabling the school to continue and keep growing to become a large-scale private school.

\section{Conclusion}

The above survey shows that the initiatial objective of the Japanese Buddhists in setting up schools was to proselytize and recruit Buddhist followers and temple workers. Such schools granted admission chiefly to the Taiwanese people and utilized the temple as a campus. The campus space was the very traditional Taiwanese temple which resembled Buddhist monasteries intended for religious practice. However, due to the limited and diminishing source of Buddhist devotees, those schools could not but weaken their religious flavor so as to boost recruiting efforts. Their new schools were built to imitate the general public schools. Such new campuses always took on a western-style look, totally different from the original religious form.

The changes resulted in changes in the social circumstances as well. Though the Japanese authorities were not willing to encourage the establishment of private schools, the craving for higher education expressed by Taiwanese people reversed the fate of those Buddhist schools, allowing them to survive and continue. As the increased students aspiring to attend school rendered the public schools insufficient, the private schools, taking advantage of needs caused by the trend toward more education came in to fill the gap. They managed to become recognized academies, and earned public school status. Such schools had to secure approval from the authorities by displaying their capability to recruit a steady number of students. To comply with the rules requiring the applicants to acquire an adequate campus site, the school owners needed to locate on larger premises. As a result, the architectural forms of the campus buildings at the new locations had to separate themselves from their host monasteries.

Monastery schools were financially burdened by increased expenditure due to the construction of new buildings when they gradually turned into general middle schools. However, the transformation of the architectural form played a significant role at this crucial juncture in the survival of private schools. The reason is that the new campus architecture was constructed not only to conform to official regulations, but also to associate a positive, progressive image with the new school. Therefore, as the students increased and government funds funneled in, eventually, the private schools solved their financial problem.

\section{Notes}

1. See Taiwan Governor-General's Office: Collection of Official Memoranda and Files. Vol. 1735. Certificate of Approval for Establishment of the Branch Monastery of the Soto Zen Head Temple of Japan and Association of Taiwanese Religious Monasteries, Shrines and Temples (1933) An Overview of the Religious Monasteries, Shrines and Temples in Taiwan: The Taipei Branch Monastery of the Soto Zen Head Temple of Japan.

2. Learned from the inscriptions on the stone tablet preserved in the Kun-yin Zen-hall.

3. See Taiwan Governor-General's Office: Collection of Official Memoranda and Files. Vol. 2516. File No. 11. Min-xue 1960 Certificates of Approval for Establishment of Taiwan Private Buddhism Middle School (Oct/1916).

4. See Taiwan Governor-General's Office: Collection of Official Memoranda and Files. Vol. 3417. The record indicates that on Sept. 29, 1922, the Soto sect application filed to the Office for changing the school name to "Private Soto Zen Taiwan Middle School" was approved. The application carried the "Rules and Regulations of the Private Soto Zen Taiwan Middle school."

5. Religious Bulletin, No. 928 (December 1, 1935) Attachment No. 11 for the Budget Proposal to Taipei Middle School Campus Expansion - Application for Subsidies for Building Construction, stating, "This year on March 16, the application for name change was approved by the governor-General's Office, we also changed from a three-year school to a five-year school and the number of students increased from 150 to 250".

6. See Private Taipei Middle School (1939) A Brief Introduction to the Private Taipei Middle Schools, p.4, "Private Taipei Middle School" was approved on Sept. 21, 1938.

7. Approval for subsidy from Taipei prefecture, official files: Edu. No. 2191-1 (Jun. 28/1939).

8. See Taiwan Governor-General's Office: Collection of Official Memoranda and Files. Vol. 5925. Statement for the Application of the Establishment of Private Middle School and the Withdrawal of the Application.

9. See the Editing Task Force of the Office of Taiwan Proselytizing Academic Affairs (1935) The Taiwan Proselytizing History of the Shin sect of Honganji-ha Buddhism, Taipei: Taiwan Monastery of Jodoshin sect Honganjiha, p.203.

\section{References}

1) Matsukane, Kimimasa. (1998) The Establishment and Development of the Japanese Buddhist Monasteries and Preaching spots in Taiwan during the Colonial Period, Studies of Taiwan History, 16, pp.18-33.

2) Shi, Hui-yen. (2003) A Review of the Educational Activities Undertaken by Taiwan's Buddhist Groups during the Japanese Rule, Chinese Buddhism Journal, 16, pp.169-209.

3) Yamamoto, Leiko. (1999) A Study of Taiwan's Women's High School in Colonial Period, Tokyo: Taga-shuppan Co.

4) Sue, Hsin-yu. (2001) A Study on the Architecture of Middle Schools and Girls' High Schools in Taiwan during the Japanese Colonial Period, Master's Thesis, National Cheng-Kung University.

5) Fuji, Yasuko. (2000) The Formation of Taiwan's Zhong Xuexiao: The Objective, System and Supporters of the Middle High Schools, Master's Thesis, National Taiwan University.

6) Matsukane, Kimimasa. (2004) The "Modernization" Process of Taiwan's Buddhism initiated and led by the Japanese Buddhist Sects - a Case Study of the Buddhist Schools run by the Soto sect, 55 (3), pp.63-92.

7) Shi, Yuan-ling. (2004) Dong-he Zen-Temple, Legal Corporate Taipei Dong-he Zen-Temple.

8) The Association of Taiwanese Religious Monasteries, Shrines and Temples. (1933) An Overview of the Religious Monasteries, Shrines and Temples in Taiwan (Taipei Prefecture): The Taipei Branch Monastery of the Soto sect Head Temple of Japan, Taipei: the Association of Taiwanese Religious Monasteries, Shrines and Temples.

9) Private Taipei Middle School. (1939) A Brief Introduction to the Private Taipei Middle Schools.

10) Taiwan Education Association. (1939) Annals of Education History, Taipei: Taiwan Education Association. 